\title{
Expression of Myc target gene mina53 in subtypes of human lymphoma
}

\author{
KWESI TEYE ${ }^{1}$, NOBUYUKI ARIMA ${ }^{2}$, YASUHIRO NAKAMURA ${ }^{3}$, KIKUO SAKAMOTO $^{4}$, \\ EIZABURO SUEOKA ${ }^{5}$, HIROSHI KIMURA ${ }^{6}$ and MAKOTO TSUNEOKA ${ }^{7}$ \\ ${ }^{1}$ Research Center for Innovative Cancer Therapy, Kurume University School of Medicine, Kurume 830-0011; \\ ${ }^{2}$ Department of Pathology, Kumamoto City Hospital, Kumamoto 862-8505; ${ }^{3}$ Department of Pathology, \\ St. Mary's Hospital, Kurume 830-8543; ${ }^{4}$ Department of Otolaryngology, Head and Neck Surgery, Kurume University \\ School of Medicine, Kurume 830-0011; ${ }^{5}$ Department of Internal Medicine, Faculty of Medicine, Saga University, \\ Saga-City, Saga 840-8502; ${ }^{6}$ Chiba Institute of Science, Choshi 288-0025; ${ }^{7}$ Department of Molecular \\ Pharmacology, Takasaki University of Health and Welfare, Takasaki, Gunma 370-0033, Japan
}

Received May 27, 2007; Accepted July 17, 2007

\begin{abstract}
Mina53 (mina) was identified as a gene, which is directly induced by the oncogene c-myc. Elevated expression of Mina53 protein was found in $>80 \%$ of colon cancer and esophageal squamous cell carcinoma (ESCC). Patients with high expression of Mina53 had shorter survival, suggesting the prognostic usefulness of Mina53. We studied Mina53 expression in lymphoma subtypes to examine its diagnostic significance and its possible role in lymphoma-genesis. Surgical cases of 28 lymphoma and 4 non-neoplastic tissues were stained immunochemically using anti-Mina53 monoclonal antibody. Mina53 expression correlated well with c-Myc expression in lymphoma, suggesting that c-Myc is a controlling factor for mina53 expression also in lymphomas. Although the expression of Mina53 as well as c-Myc was less frequent in lymphoma compared with those of colon and ESCC, increased expression of Mina53 was found in Burkitt-like lymphoma (1/1), Hodgkin's lymphoma (3/5), diffuse large B cell lymphoma (DLBCL) (5/13), lymphomas with a transition from follicular to DLBCL (1/2), with none in follicular $(0 / 4)$ and $\mathrm{T}$ cell lymphoma $(0 / 3)$. Analyses of the data suggested that Mina53 was frequently expressed in aggressive types of B cell lymphoma. To get more information about the expression of Mina53 in DLBCL, which most frequently occurs among lymphomas, we analyzed the expression of Mina53 in another 21 DLBCL specimens, which were in more advanced stages than those
\end{abstract}

Correspondence to: Dr Makoto Tsuneoka, Laboratory of Molecular and Cellular Biology, Department of Molecular Pharmacology, Faculty of Pharmacy, Takasaki University of Health and Welfare, 60 Nakaorui-machi, Takasaki, Gunma 370-0033, Japan

E-mail: tsuneoka@takasaki-u.ac.jp

Key words: immunohistochemistry, lymphoma, Mina53, c-Myc described above. The expression level of Mina53 correlated to the international prognostic index (IPI) values with statistical significance $(r=0.477, \mathrm{P}=0.0275)$. Notably, in this group, Mina53 expression did not correlate with c-Myc expression, suggesting that other factor(s) besides c-Myc largely affect the expression of Mina53 in advanced DLBCL. These results suggest that although Mina53 expression is not prominent in lymphoma in general, it may be related to tumor progression of B cell lymphoma.

\section{Introduction}

The c-myc proto-oncogene belongs to a family of related genes, which include L-myc and N-myc (1). Deregulated expression of c-myc is common in cancer and the activation of $c-m y c$ by chromosomal translocation, gene amplification and proviral insertion was described in a variety of tumors from several species, including humans (2-5). Constitutive c-myc expression inhibits exit from the cell cycle and abolishes differentiation $(1,6)$. c-Myc activity is sufficient to drive quiescent cells into the cell cycle in the absence of growth factors (7). Studies in rodent model systems have shown that overexpression of c-Myc can cause malignant transformation and that sustained tumor growth depends on its continued expression (8-11). Thus, c-Myc is a potent and critical promoter of tumor cell proliferation.

Although the precise mechanism remains poorly understood, c-Myc is thought to exert its biological effects by regulating the expression of target genes $(12,13)$. To date, many Myc target genes have been identified. While many of them are related to cell proliferation, they have a variety of functions and their modes of contribution to tumorigenesis are different to each other. A novel gene, mina53, whose expression was demonstrated through experimental evidence to be directly induced by $c-m y c$ has been identified (14). The mina53 gene encodes a protein with a molecular weight of 53 $\mathrm{kDa}$ that is localized in the nucleus. Expression of mina53 is increased during cell proliferation and specific inhibition of mina53 expression by an RNA interference (RNAi) method 
suppressed cell proliferation in certain cultured cell lines (1416). Using a specific monoclonal antibody against human Mina53 protein, it was found that expression of Mina53 is frequently increased in human colon cancer (15) and esophageal squamous cell carcinoma (ESCC) (16), but not in non-neoplastic well proliferating cells. In the case of ESCC, patients with high expression of Mina53 had shorter survival (16). These results suggest that Mina53 is a cancer related protein, which may play a role in c-Myc-induced carcinogenesis.

It is difficult to predict the prognosis of lymphoma. Although the International Prognostic Index (IPI) is useful in predicting the outcome of Diffuse large B cell lymphoma (DLBCL), patients with identical IPI still exhibit a marked variety in survival and additional molecular markers should help the diagnosis of the disease (17). In human lymphoma, translocation of the $c-m y c$ gene to the heavy or light chain of the immunoglobulin locus is seen in virtually every case of Burkitt's lymphoma and in certain cases of lymphomas that have progressed from indolent ones (18-21). The presence of $c$-myc rearrangements in higher-grade tumors may suggest a role for c-Myc in the clonal evolution of low-grade tumors into more aggressive lymphomas (22). Transcription of the translocated $c$-myc gene is greater than that seen in resting $\mathrm{B}$ cells $(20,23)$. A subgroup of patients with dual translocation of $c-m y c$ and $b c l-2$ appear to have an extremely poor outcome despite high-dose chemotherapy (24). c-Myc induces lymphoma in the bursa of Fabricius in bird $(25,26)$. Transgenic mice bearing $c-m y c$ gene developed clonal B cell malignancies and constitutive expression of c-Myc caused human B lymphoblastic cells that were immortalized by the Epstein-Barr virus to be tumorigenic in immunodeficient mice $(8,27,28)$. These results suggest that c-Myc plays a causal role in lymphomagenesis and may be associated with tumor progression.

We studied the expression of Mina53 in several subtypes of lymphoma using immunohistochemical methods to examine a possible role of Mina53 in lymphoma-genesis. We showed that Mina53 is markedly expressed in certain subtypes of lymphoma.

\section{Materials and methods}

Antibodies. Anti-human Mina53 mouse monoclonal antibody M532 was used in this study. The specificity of M532 to human Mina53 was demonstrated in a previous study (15). Rabbit anti-c-Myc polyclonal antibody (sc-764) (Santa Cruz Biotechnology, Santa Cruz, CA), mouse anti-Ki-67 monoclonal antibody (clone MIB-1) (Dako A/S, Glostrup, Denmark), peroxidase-labeled goat anti-mouse IgG Fab' (Nichirei, Tokyo, Japan) and peroxidase-labeled goat antirabbit IgG Fab' (Nichirei) were purchased.

Tissues for immunostaining. Routinely processed formalinfixed and paraffin-embedded specimens from 28 patients with lymphoma were obtained from the Department of Otolaryngology, Kurume University Hospital and St. Mary's Hospital, Kurume. The sections included B cell lymphomas $(n=25)$ and T cell lymphomas $(n=3)$. The sections for B cell lymphomas were classified into the major subtypes of lymphoma as follicular lymphoma $(\mathrm{n}=4)$, diffuse large B cell lymphoma $(n=13)$, Hodgkin's lymphoma $(n=5)$ and Burkittlike lymphoma $(n=1)$. There were also 2 cases in which there was a transition from follicular to diffuse large B cell lymphoma. Four apparently non-neoplastic lymphoid tissues were also used in this study. The characteristics of the tissues are outlined in Table I. Additional routinely processed formalin-fixed and paraffin-embedded specimens from 21 patients with diffuse large B cell lymphoma were obtained from the Department of Internal Medicine, Saga University Hospital.

Immunostaining of lymphoma tissues. Immunostaining was performed essentially as previously described (15) with minor modifications. Briefly, thin sections of formalin-fixed, paraffin-embedded tissue specimens were mounted on glass slides, deparaffinized, hydrated and autoclaved for $20 \mathrm{~min}$ in $10 \mathrm{mM}$ sodium citrate buffer, $\mathrm{pH}$ 6.0, for antigen retrieval. After pretreatment with $3 \% \mathrm{H}_{2} \mathrm{O}_{2}$ in PBS and then with $1 \%$ skim milk in PBS, sections were incubated with the primary antibodies overnight at $4^{\circ} \mathrm{C}$ and then with peroxidase-labeled goat anti-mouse IgG Fab' or peroxidase-labeled goat anti-rabbit IgG Fab' (Nichirei). Color was developed with 3,3diaminobenzidine and $\mathrm{H}_{2} \mathrm{O}_{2}$. After light counterstaining with haematoxylin, the slides were dehydrated, coverslipped and observed with an Olympus AX80 microscope (Olympus Optical, Tokyo, Japan).

Evaluation of immunostaining. The staining intensity of each section was scored on a scale from 0 to 4 by visual observation. The section with the highest staining intensity was scored as 4 , the lowest as 1 and no staining at all as 0 . The percentage of tumor cells stained by the antibodies was also estimated as 0, 0-50, 50, 50-100 and 100\%. The staining index was calculated as the staining intensity $x$ percentage of cells stained. For calculation of the staining index, the percentage of cells stained was estimated as 0, 25, 50, 75 and $100 \%$. Sections were defined as positive or increased expression when the staining intensity was higher than the average staining intensity of the non-neoplastic tissues. The correlations between the staining intensities of the proteins were examined by using the Spearman rank correlation coefficient.

\section{Results}

Mina53 expression in lymphoma. Anti-Mina53 monoclonal antibody was used to examine the expression of Mina53 in lymphoma tissues. Initially, Mina53 expression was investigated in 4 apparently non-neoplastic lymphoid tissues. As shown in Table I, Mina53 was only weakly expressed in 3 cases, while no expression was detected in the other case. These results were consistent with our previous results $(15,16)$.

The section shown in Fig. 1a contained diffuse large B cell lymphoma (DLBCL) and Mina53 was markedly expressed in the tumor cells. When the expression of Mina53 was analyzed in 13 cases of DLBCL, 5 cases $(38.5 \%)$ contained elevated amounts of Mina53, compared to lymphocytes in the nonneoplastic tissues (Table II). The section shown in Fig. 1b contained follicular lymphoma, in which Mina53 expression 
Table I. Characteristics of lymphoma tissues and summary of immunohistochemistry.

\begin{tabular}{|c|c|c|c|c|c|c|c|c|c|c|c|c|}
\hline \multirow[t]{2}{*}{ No. } & \multirow[t]{2}{*}{ Age } & \multirow[t]{2}{*}{ Sex } & \multirow{2}{*}{$\begin{array}{l}\text { Histological } \\
\text { type }\end{array}$} & \multicolumn{3}{|c|}{ Staining intensity } & \multicolumn{3}{|c|}{$\%$ Tumor cells stained } & \multicolumn{3}{|c|}{ Staining index } \\
\hline & & & & Mina53 & Myc & $\mathrm{Ki}-67$ & Mina53 & Myc & Ki-67 & Mina53 & Myc & Ki-67 \\
\hline 1 & 67 & $\mathrm{~F}$ & DLBCL & 0 & 1.5 & 3 & 0 & $0-50$ & $0-50$ & 0 & 37.5 & 75 \\
\hline 2 & 71 & $\mathrm{M}$ & DLBCL & 1 & 3 & 3 & 100 & 100 & 100 & 100 & 300 & 300 \\
\hline 3 & 45 & $\mathrm{M}$ & DLBCL & 1 & 2 & 4 & $0-50$ & $0-50$ & $50-100$ & 25 & 50 & 300 \\
\hline 4 & 63 & $\mathrm{~F}$ & DLBCL & 1 & 2 & 4 & 50 & $50-100$ & $50-100$ & 50 & 150 & 300 \\
\hline 5 & 80 & $\mathrm{M}$ & DLBCL & 1 & 2 & 3 & $50-100$ & $50-100$ & $50-100$ & 75 & 150 & 225 \\
\hline 6 & 72 & $\mathrm{~F}$ & DLBCL & 1 & 1.5 & 3 & 50 & $0-50$ & $50-100$ & 50 & 37.5 & 225 \\
\hline 7 & 57 & $\mathrm{M}$ & DLBCL & 1 & 3 & 3 & 100 & 50 & $50-100$ & 100 & 150 & 225 \\
\hline 8 & 80 & $\mathrm{M}$ & DLBCL & 1 & 3 & 3 & $50-100$ & 100 & $50-100$ & 75 & 300 & 225 \\
\hline 9 & 76 & $\mathrm{M}$ & DLBCL & 1.5 & 3 & 3 & 100 & 100 & $50-100$ & 150 & 300 & 225 \\
\hline 10 & 63 & $\mathrm{M}$ & DLBCL & 2 & 2 & 3 & 100 & 100 & 100 & 200 & 200 & 300 \\
\hline 11 & 54 & $\mathrm{M}$ & DLBCL & 2 & 3 & 4 & 100 & 100 & 100 & 200 & 300 & 400 \\
\hline 12 & 60 & $\mathrm{M}$ & DLBCL & 2 & 3 & 3 & 100 & 100 & $50-100$ & 200 & 300 & 225 \\
\hline 13 & 43 & $\mathrm{M}$ & DLBCL & 3 & 3 & 4 & 100 & 100 & $50-100$ & 300 & 300 & 300 \\
\hline 14 & 52 & $\mathrm{~F}$ & FL & 0 & 1 & 3 & 0 & 25 & $0-50$ & 0 & 25 & 225 \\
\hline 15 & 53 & $\mathrm{M}$ & FL & 1 & 1 & 3 & 50 & $0-50$ & 100 & 50 & 25 & 300 \\
\hline 16 & 44 & $\mathrm{M}$ & FL & 1 & 2 & 3 & 100 & 100 & $0-50$ & 100 & 200 & 75 \\
\hline 17 & 56 & $\mathrm{M}$ & FL & 0 & 1 & 3 & 0 & $10-50$ & $0-50$ & 0 & 25 & 75 \\
\hline 18 & 50 & $\mathrm{M}$ & FL $>$ DLBCL & 1 & 1 & 3 & $50-100$ & $50-100$ & $0-50$ & 75 & 75 & 75 \\
\hline 19 & 47 & $\mathrm{~F}$ & FL $>$ DLBCL & 1.5 & 3 & 3 & 100 & 100 & $50-100$ & 150 & 300 & 225 \\
\hline 20 & 18 & $\mathrm{M}$ & LRCHL & 1 & 1 & 3 & $50-100$ & 50 & 100 & 75 & 50 & 300 \\
\hline 21 & 74 & M & NSHL & 0 & 2 & 3 & 0 & 100 & 100 & 0 & 200 & 300 \\
\hline 22 & 34 & $\mathrm{M}$ & NSHL & 1.5 & 1 & 3 & $50-100$ & 10 & $50-100$ & 112.5 & 25 & 150 \\
\hline 23 & 18 & $\mathrm{M}$ & NSHL & 2 & 2 & 3 & 100 & 100 & $50-100$ & 200 & 200 & 225 \\
\hline 24 & 65 & $\mathrm{M}$ & MCHL & 3 & 3 & 3 & 100 & 100 & 100 & 300 & 300 & 300 \\
\hline 25 & 75 & $\mathrm{~F}$ & TCL & 0 & 1 & 3 & 0 & $0-50$ & $0-50$ & 0 & 25 & 75 \\
\hline 26 & 68 & $\mathrm{~F}$ & TCL & 1 & 2 & 3 & $50-100$ & 50 & $50-100$ & 75 & 100 & 225 \\
\hline 27 & 30 & M & TCL & 0 & 1 & 3 & 0 & $0-50$ & $50-100$ & 0 & 25 & 225 \\
\hline 28 & 55 & $\mathrm{M}$ & $\mathrm{BL}$ & 4 & 3 & 4 & 100 & 100 & 100 & 300 & 400 & 300 \\
\hline 29 & 19 & $\mathrm{~F}$ & $\mathrm{~N}$ & 1 & 2 & 3 & 50 & $0-50$ & 100 & 50 & 50 & 300 \\
\hline \multirow[t]{2}{*}{30} & 79 & $\mathrm{~F}$ & $\mathrm{~N}^{\mathrm{a}}$ & 1.5 & 2 & 3 & $0-50$ & $0-50$ & 100 & 37.5 & 50 & 300 \\
\hline & & & $\mathrm{b}$ & 1.5 & 2 & 3 & $0-50$ & $0-50$ & 10 & 37.5 & 50 & 30 \\
\hline 31 & 56 & $\mathrm{M}$ & $\mathrm{N}$ & 0 & 2 & 3 & 0 & $0-50$ & 100 & 0 & 50 & 300 \\
\hline 32 & 60 & $\mathrm{M}$ & $\mathrm{N}$ & 1 & 2 & 3 & 100 & $0-50$ & $50-100$ & 100 & 50 & 225 \\
\hline
\end{tabular}

DLBCL, Diffuse large B cell lymphoma; FL, follicular lymphoma; FL $>$ DLBCL, contained follicular and diffuse large B cell lymphoma; LRCHL, Lymphocyte-rich classical Hodgkin's lymphoma; NSHL, Nodular sclerosis Hodgkin's lymphoma; MC Hodgkin's lymphoma, Mixed cellularity Hodgkin's lymphoma; TCL, T cell lymphoma; BLL, Burkitt-like lymphoma; N, non-neoplastic. ${ }^{a}$ Germinal center B cells. ${ }^{b}$ Non-germinal B cells.

was hardly detected. As demonstrated in Table II, all cases of follicular lymphoma did not show increased expression of Mina53. There were two cases (\#18 and \#19) with a transition from follicular to diffuse large B cell lymphoma in which Mina53 expression was slightly increased in 1 case $(50 \%)$ (Table II). It was shown that diffuse large B cell lymphoma is more aggressive than follicular B cell lymphoma and some proportion of follicular B cell lymphomas progress to diffuse large B cell lymphoma $(29,30)$.

The section shown in Fig. 1c contained a mixed cellularity Hodgkin's lymphoma (MCHL). Tumor cells were markedly stained by anti-Mina53 antibody (Table II) whereas most non-neoplastic cells showed little staining (Fig. 1c). Elevated expression of Mina53 was found in 2 out of 3 cases of nodular sclerosis Hodgkin's lymphoma (NSHL) (Tables I and II), but not in the 1 case of lymphocyte-rich classical Hodgkin's lymphoma (LRCHL) (Tables I and II). It was revealed that MCHLs are more aggressive than NSHLs and that LCHLs show far less aggressive clinical behavior (31-33). Therefore, while Mina53 expression was increased in $60 \%$ of all cases of Hodgkin's lymphoma (Table II), aggressive forms of Hodgkin's lymphoma tend to express Mina53 highly and frequently (Tables I and II).

We investigated one case of Burkitt-like lymphoma, a very aggressive lymphoma and it was found that Mina53 was highly expressed in the tumor cells of the lymphoma (Fig. 1d). All cases of T cell type lymphoma (3/3) showed very little or no expression of Mina53 (Tables I and II). Thus, our results above suggest that increased expression of Mina53 is associated with high-grade B cell lymphoma. 

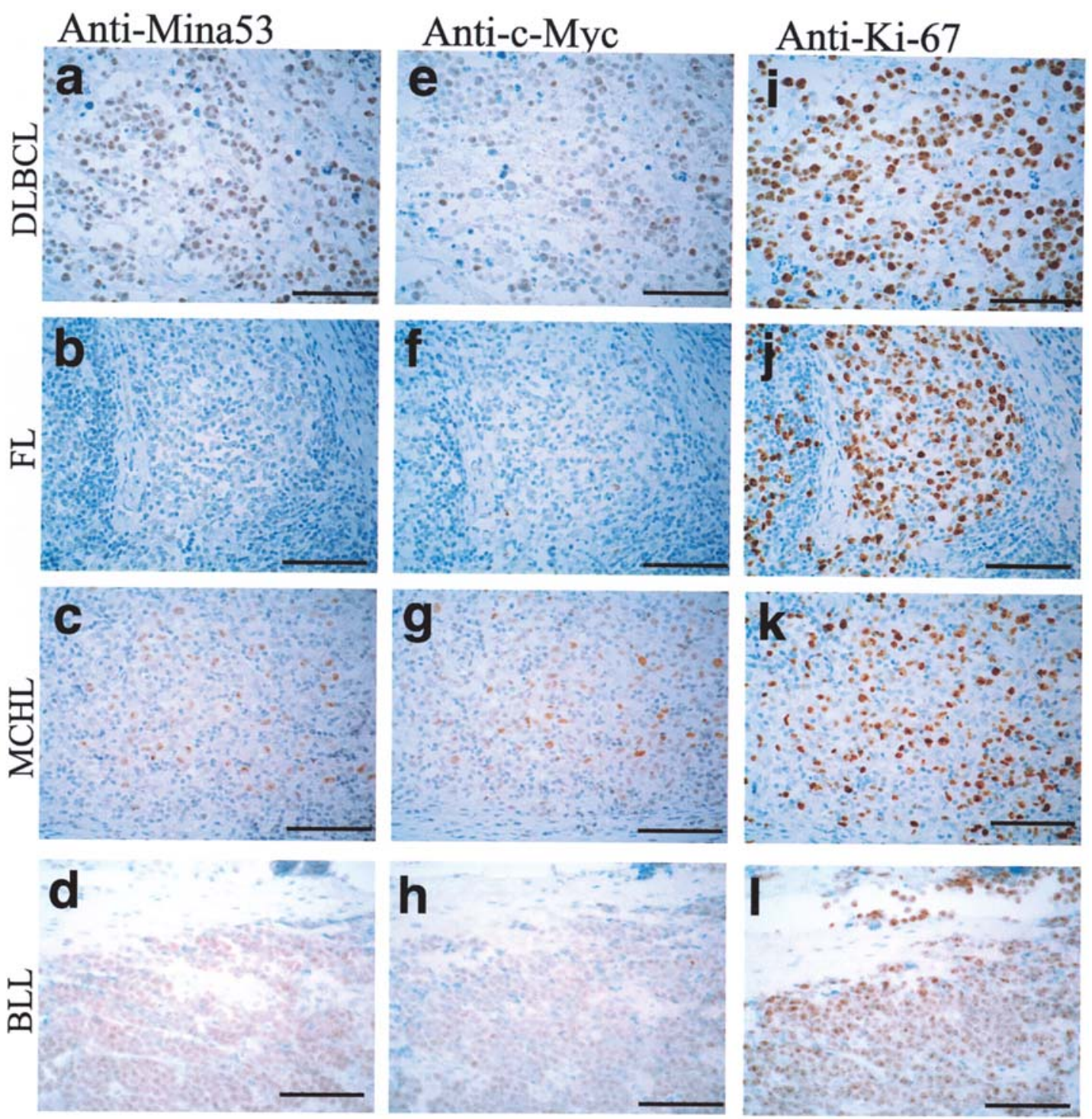

Figure 1. Immunohistochemical analysis of Mina53, Myc and Ki-67 proteins in lymphoma tissues. Serial sections were stained by anti-Mina53 (left), anti-c-Myc (middle), or anti-Ki-67 (right) antibody. Staining of diffuse large B cell lymphoma for Mina53 (a), Myc (e), or Ki-67 (i). Section (a) showed marked expression of Mina53 in tumor cells. Staining of follicular lymphoma for Mina53 (b), c-Myc (f) or Ki-67 (j). Section (b) showed lack of Mina53 expression. Staining of a mixed cellularity Hodgkin's lymphoma for Mina53 (c), c-Myc (g), or Ki-67 (k). Section (c) showed marked Mina53 expression. Staining of Burkitt-lymphoma for Mina53 (d), c-Myc (h), or Ki-67 (1). Section (d) showed high expression of Mina53. Scale bars, $75 \mu \mathrm{m}$.

Table II. Summary of Mina53 staining in lymphoma by histological type.

\begin{tabular}{|c|c|c|c|c|c|c|c|c|c|}
\hline \multirow{2}{*}{$\begin{array}{l}\text { Histological } \\
\text { Туре }^{\text {a }}\end{array}$} & \multirow[t]{2}{*}{ Cases } & \multicolumn{6}{|c|}{ Mina53 staining intensity } & \multicolumn{2}{|c|}{ Positive rate (\%) } \\
\hline & & - & + & +1.5 & +2 & +3 & +4 & Mina53 & Myc \\
\hline DLBCL & 13 & 1 & 7 & 1 & 3 & 1 & 0 & 38.5 & 53.8 \\
\hline FL & 4 & 2 & 2 & 0 & 0 & 0 & 0 & 0 & 0 \\
\hline FL $>$ DLBCL & 2 & 0 & 1 & 1 & 0 & 0 & 0 & 50 & 50 \\
\hline LRCHL & 1 & 0 & 1 & 0 & 0 & 0 & 0 & 0 & 0 \\
\hline NSHL & 3 & 1 & 0 & 1 & 1 & 0 & 0 & 66.7 & 0 \\
\hline MCHL & 1 & 0 & 0 & 0 & 1 & 1 & 0 & 100 & 100 \\
\hline BLL & 1 & 0 & 0 & 0 & 0 & 1 & 1 & 100 & 100 \\
\hline TCL & 3 & 1 & 2 & 0 & 0 & 0 & 0 & 0 & 0 \\
\hline
\end{tabular}

${ }^{a}$ DLBCL, Diffuse large B cell lymphoma; FL, follicular lymphoma; FL $>$ DLBCL, contained follicular and diffuse large B cell lymphoma; LRCHL, Lymphocyte-rich classical Hodgkin's lymphoma; NSHL, Nodular sclerosis Hodgkin's lymphoma; MCHL, Mixed cellularity Hodgkin's lymphoma; TCL, T cell lymphoma; BLL, Burkitt-like lymphoma. 
Table III. Summary of Mina53 and c-Myc expression in a subset of DLBCL lymphoma.

\begin{tabular}{|c|c|c|c|c|c|c|c|c|}
\hline \multirow[t]{2}{*}{ Patient No. } & \multirow[t]{2}{*}{ Age } & \multirow[t]{2}{*}{ Gender } & \multirow[t]{2}{*}{ Subtype } & \multicolumn{2}{|c|}{ Staining intensity } & \multicolumn{2}{|c|}{ Staining index } & \multirow[t]{2}{*}{ IPI } \\
\hline & & & & Mina53 & Myc & Mina53 & Myc & \\
\hline 33 & 38 & $\mathrm{~F}$ & NonGCB DLBL & 2 & 1 & 150.0 & 25.0 & 3 \\
\hline 34 & 75 & $\mathrm{~F}$ & GCB DLBL & 1 & 1 & 50.0 & 25.0 & 1 \\
\hline 35 & 59 & $\mathrm{~F}$ & NonGCB DLBL & 2.5 & 1 & 250.0 & 25.0 & 3 \\
\hline 36 & 63 & $\mathrm{~F}$ & GCB DLBL & 1.5 & 1 & 112.5 & 25.0 & 3 \\
\hline 37 & 67 & M & NonGCB DLBL & 1 & 2 & 50.0 & 150.0 & 1 \\
\hline 38 & 80 & $\mathrm{~F}$ & NonGCB DLBL & 2 & 3 & 200.0 & 225.0 & 2 \\
\hline 39 & 56 & M & NonGCB DLBL & 1.5 & 1 & 112.5 & 25.0 & 4 \\
\hline 40 & 79 & $\mathrm{~F}$ & GCB DLBL & 2.5 & 1 & 250.0 & 25.0 & 5 \\
\hline 41 & 32 & $\mathrm{~F}$ & GCB DLBL & 2 & 1.5 & 200.0 & 37.5 & 3 \\
\hline 42 & 47 & M & NonGCB DLBL & 2 & 3 & 200.0 & 225.0 & 2 \\
\hline 43 & 69 & M & NonGCB DLBL & 3 & 2 & 300.0 & 150.0 & 5 \\
\hline 44 & 65 & M & GCB DLBL & 2 & 2.5 & 200.0 & 187.5 & 1 \\
\hline 45 & 63 & M & GCB DLBL & 3 & 2 & 300.0 & 150.0 & 3 \\
\hline 46 & 73 & $\mathrm{~F}$ & NonGCB DLBL & 3 & 1 & 225.0 & 25.0 & 2 \\
\hline 47 & 72 & $\mathrm{~F}$ & GCB DLBL & 2 & 1 & 150.0 & 25.0 & 4 \\
\hline 48 & 65 & M & NonGCB DLBL & 2 & 3 & 200.0 & 75.0 & 3 \\
\hline 49 & 41 & M & NonGCB DLBL & 2 & 1 & 200.0 & 25.0 & 1 \\
\hline 50 & 78 & $\mathrm{~F}$ & GCB DLBL & 2.5 & 2 & 250.0 & 100.0 & 4 \\
\hline 51 & 62 & $\mathrm{~F}$ & GCB DLBL & 3 & 2 & 300.0 & 150.0 & 4 \\
\hline 52 & 75 & M & GCB DLBL & 4 & 1 & 400.0 & 25.0 & 3 \\
\hline 53 & 62 & M & NonGCB DLBL & 1 & 2 & 100.0 & 50.0 & 1 \\
\hline Average & & & & & & 200.0 & 83.3 & 2.8 \\
\hline
\end{tabular}

Table IV. Correlation between Mina53 expression and other factors.

\begin{tabular}{|c|c|c|c|c|}
\hline Factors & Cases & $\mathrm{r}$ & $95 \% \mathrm{CI}$ & $\mathrm{P}$ \\
\hline \multicolumn{5}{|c|}{ All lymphoma cases } \\
\hline Mina53, Myc & 28 & 0.775 & $0.565-0.891$ & $<0.0001$ \\
\hline Mina53, Ki-67 & 28 & 0.427 & $0.064-0.690$ & 0.0225 \\
\hline
\end{tabular}

Diffuse large B cell lymphoma with low average IPI value

\begin{tabular}{|c|c|c|c|c|}
\hline Mina53, Myc & 13 & 0.724 & $0.288-0.911$ & 0.0038 \\
\hline Mina53, Ki-67 & 13 & 0.490 & $-0.084-0.820$ & 0.0900 \\
\hline Mina53, IPI & 12 & -0.402 & $-0.793-0.223$ & 0.2007 \\
\hline Myc, IPI & 12 & 0.093 & $-0.508-0.633$ & 0.7803 \\
\hline
\end{tabular}

Diffuse large B cell lymphoma with high average IPI value

\begin{tabular}{lllll}
\hline Mina53, Myc & 21 & 0.157 & $-0.295-0.551$ & 0.503 \\
Mina53, IPI & 21 & 0.477 & $-0.058-0.754$ & 0.0275 \\
Myc, IPI & 21 & -0.149 & $-0.508-0.633$ & 0.5230 \\
\hline
\end{tabular}

CI, confidence interval. ${ }^{\mathrm{a}}$ For diffuse large B cell lymphoma subgroup.

Expression of Mina53 in diffuse large B cell lymphomas with more advanced stages. The results above suggest that increased expression of Mina53 may be associated with advanced stages in some cases of B cell lymphomas. However, when staining index of Mina53 was compared with IPI values (international prognostic index), no correlation was observed (Table IV). This may be due to the fact that there are few progressed cancer specimens examined. In the specimens in Table I, the lymphomas have relatively lower IPI values (the average of the IPI value was 1.7), because most of the specimens were obtained from the Department of Otolaryngology, where patients with early stages of the lymphomas usually receive surgical treatment. To clarify this point, the expression of Mina53 was further examined in another 21 cases 
of DLBCL with more advanced stages (the average of the IPI value was 2.8), which were obtained from the Department of internal medicine. The results are shown in Table III. When the staining index of Mina53 was compared to IPI values, a positive correlation was found between them with statistical significance $(r=0.477, \mathrm{P}=0.0275)$. These results suggest that Mina53 is highly expressed in aggressive DLBCL.

c-Myc was also stained in these specimens. Notably, the staining level of c-Myc was not similar to that of Mina53 $(\mathrm{r}=0.157, \mathrm{p}=0.5030)$ (Tables III and IV). In this group, the averages of staining indices for c-Myc and Mina53 were 83.3 and 200, respectively (Table III), while those for c-Myc and Mina53 were 198 and 117, respectively, in the group of DLBCL with lower IPI values (Table I). Although these values are not directly compared between two groups, which were obtained from different hospitals, the results suggest that the expression of Mina53 is higher in the group of patients with the high average of the IPI, while that of c-Myc is higher in the group of patients with the low average of the IPI.

Comparison of expression of Mina53, Myc and Ki-67 in lymphoid tissues. Serial sections from the above specimens were stained with anti-c-Myc antibody. c-Myc was detected in certain lymphoma tissues, including diffuse large B cell lymphoma (Fig. 1e-h). The staining level of c-Myc in each section was quite similar to that of Mina53 ( $\mathrm{r}=0.775$, $\mathrm{p}<0.0001$ ) (Table IV and Fig. 1). These results suggest that Mina53 expression is generally closely related to c-Myc expression in lymphoid cells. However, as mentioned above, expression of Mina53 did not correlate with that of c-Myc in the specimens with advanced DLBCL (Tables III and IV).

The expression of Ki-67, a well-used cell proliferation marker, was also investigated in serial sections in all cases shown in Table I. As reported before (34,35), anti-Ki-67 antibody stained lymphoma tissues intensely (Fig. 1i-1). In all cases, an antibody against Ki-67 stained tumor cells strongly and frequently. Ki-67 staining was also detected in follicular lymphoma lacking Mina53 and c-Myc staining [Fig. 1b (Mina53), f (Myc) and j (Ki-67)]. The staining levels of Mina53 showed a statistically significant correlation with those of Ki-67 (r=0.427, p=0.0225) (Table IV and Fig. 1), suggesting that Mina53 is related to cell proliferation in lymphoma. However, Ki-67 was also highly expressed in nearly all cells in the non-neoplastic germinal center, in which Mina53 was faintly expressed (Table I; \#30). Thus Mina53 is not always expressed in proliferating cells.

\section{Discussion}

The elevation of Mina53 expression is frequently found in some aggressive types of lymphomas. In our previous studies we demonstrated that Mina53 is highly expressed in $>80 \%$ of ESCC and colon cancer cases and it was suggested that increased expression of Mina53 is a hallmark in these cancers $(15,16)$. In this study we found that although the expression of Mina53 was less frequent in lymphoma, Mina53 is markedly expressed in one third of all lymphoma cases (Table I).

Mina53 is poorly expressed in non-neoplastic lymphoid tissues including germinal centers. Burkitt-like lymphoma, an aggressive form of lymphoma, showed very high expression of
Mina53. We also found very high expression of Mina53 in Burkitt's lymphoma cell line Daudi (data not shown). Among Hodgkin's lymphomas, Mina53 expression was strongest and most frequent in MCHL, which is the most aggressive, followed by NSHL, which is intermediate grade, with none in the indolent LRCHL (Table I). Mina53 expression was found frequently in DLBCL but not in follicular B cell lymphomas. In a group of DLBCL with relatively advanced stages (Table III), there was positive correlation between them with statistical significance $(r=0.477, P=0.0275$, Table IV). These results suggest that Mina53 expression was found more often in aggressive DLBCL. Together, these results suggest that Mina53 may be activated during the transformation from indolent to more aggressive forms of the disease.

Mina53 expression is cell type-specific rather than cell proliferation-specific. The expression of Mina53 was compared with that of Ki-67, a widely used biomarker for cell proliferation. We noted strong and frequent expression of Ki-67 in lymphoma (Fig. 1 and Table I) and that Ki-67 was also strongly expressed in non-neoplastic lymphoid tissues. On the other hand, Mina53 expression was confined specifically to tumor cells, suggesting that Mina53 is dispensable for cell proliferation of non-neoplastic lymphocyte. Therefore, Mina53 may not directly be involved in basic mechanisms of cell proliferation but plays a role in the pathogenesis of certain B cell lymphoma.

There is precedence that the expression of Mina53 is not associated with cell proliferation. In mouse testis there is a prominently high expression of Mina53 in some oval-shaped cells in the periphery of the seminiferous epithelium of normal adult testis, which appears to be well-proliferating type A spermatogonia. However, the expression of Mina53 was also detected in Sertoli cells and even in the Leydig cells, which are highly differentiated and actively functioning but no longer dividing (36). These results suggest that the expression of Mina53 is cell type-specific but not cell proliferation-specific.

Control of Mina53 expression. In this study we found that Mina53 expression correlated well with that of c-Myc $(r=0.724, \mathrm{P}=0.0038)$ in the specimen with relatively low IPI values. These results suggest that c-Myc largely determined Mina53 expression in lymphoma at the early stages. However, in another 21 specimens of DLBCL with relatively high IPI values, the staining indices of c-Myc were different from those of Mina53 ( $\mathrm{r}=0.157, \mathrm{p}=0.5030$ ) (Table IV). Therefore, in advanced stages of DLBCL Mina53 expression increased without high expression of c-Myc. As mentioned above, the expression of Mina53 was detected in Sertoli cells and the Leydig cells, which were shown not to express c-myc (37). Thus these results suggest that there should be other controlling molecule(s) for mina53 expression besides $c$-myc in testicular somatic cells and advanced DLBCL.

Lymphomagenesis and $c-M y c . c-M y c$ translocations are present in virtually all cases of Burkitt's lymphoma (18-21). In our study, the expression of c-Myc was also high in this disease (Fig. 1 and Table I). Aggressive forms of Hodgkin's lymphoma tend to express c-Myc as well as Mina53 highly and frequently (Tables I and II). These results suggest that in 
these two types of B cell lymphomas, the elevated expression of c-Myc appears to be correlated to aggressiveness.

In DLBCL, c-Myc level did not correlate with IPI especially in the group of aggressive DLBCL (Tables III and IV). This suggests that although the high level expression of c-Myc may contribute to tumorigenesis in the early stages of DLBCL, it may be dispensable in the advanced stage. A similar observation was previously reported. Results from gene expression profile analysis performed before and after follicular lymphomas were transformed to DLBCL showed that expression levels of c-Myc can be increased, decreased, or unchanged during the transformation (38). Large scale analysis of gene expression during myc-induced lymphomagenesis in the bursa of Fabricius revealed that while overexpression of $m y c$ results in transformation, expression profiles of late metastatic tumors showed a large variation in myc overexpression levels and some showed minimal myc overexpression (26). These results together with the results described in this report suggest that overexpression of myc may be important for the early induction of these lymphomas than the maintenance of late-stage metastases.

Since c-Myc controls the expression of many genes that are related to cell proliferation, the change of only one gene c-myc can largely contribute to cell proliferation. Indeed, c-Myc activation induced proliferation and tumorigenic ability of pancreatic cells without additional genetic changes when apoptosis was suppressed (39). However, during the progression of the disease, many mutations are accumulated, many of which favor cell proliferation. At that stage c-Myc expression becomes dispensable and/or reduction of c-Myc expression would give an advantage for carcinogenesis since one Myc function, the ability inducing apoptosis, is unfavorable for cell proliferation.

In conclusion, we found that the elevated expression of Mina53 is associated with some specific subtypes of lymphoma, most plausibly in subtypes of high-grade B cell lymphoma, suggesting that Mina53 staining may allow patient selection for systematic therapies.

\section{Acknowledgements}

This study was supported by Grants-in-Aid from the Ministry of Education, Science, Japan, Grants-in-Aid from Fukuoka Gann and The Japanese Society for the Promotion of Science. We thank Miss Yasuko Noguchi, Department of Forensic Medicine, Kurume University School of Medicine, for her technical assistance.

\section{References}

1. Henriksson M and Lüscher B: Proteins of the Myc network: essential regulators of cell growth and differentiation. Adv Cancer Res 68: 109-182, 1996.

2. Kelly $\mathrm{K}$ and Siebenlist $\mathrm{U}$ : The regulation and expression of c-myc in normal and malignant cells. Annu Rev Immunol 4: 317-338, 1986.

3. DePinho RA, Schreiber-Agus N and Alt FW: myc family oncogenes in the development of normal and neoplastic cells. Adv Cancer Res 57: 1-46, 1991

4. Spencer CA and Groudine M: Control of c-myc regulation in normal and neoplastic cells. Adv Cancer Res 56: 1-48, 1991.

5. Nesbit C, Tersakk J and Prochownik E: Myc oncogenes and human neoplastic disease. Oncogene 18: 3004-3016, 1999.
6. Marcu KB, Bossone SA and Patel AJ: myc function and regulation. Annu Rev Biochem 61: 809-858, 1992.

7. Eilers M, Schirm S and Bishop J: The MYC protein activates transcription of the alpha-prothymosin gene. EMBO J 10: 133-141, 1991.

8. Adams JM, Harris AW, Pinkert CA, Corcoran LM, Alexander WS, Cory S, Palmiter RD and Brinster RL: The c-myc oncogene driven by immunoglobulin enhancers induces lymphoid malignancy in transgenic mice. Nature 318: 533-538, 1985.

9. Leder A, Pattengale PK, Kuo A, Stewart TA and Leder P: Consequences of widespread deregulation of the c-myc gene in transgenic mice: multiple neoplasms and normal development. Cell 45: 485-495, 1986.

10. Felsher DW and Bishop JM: Reversible tumorigenesis by MYC in hematopoietic lineages. Mol Cell 4: 199-207, 1999.

11. Marinkovic D, Marinkovic T, Mahr B, Hess J and Wirth T: Reversible lymphomagenesis in conditionally c-MYC expressing mice. Int J Cancer 110: 336-342, 2004.

12. Facchini LM and Penn LZ: The molecular role of Myc in growth and transformation: recent discoveries lead to new insights. FASEB J 12: 633-651, 1998.

13. Cole MD and McMahon SB: The Myc oncoprotein: a critical evaluation of transactivation and target gene regulation. Oncogene 18: 2916-2924, 1999.

14. Tsuneoka M, Koda Y, Soejima M, Teye K and Kimura H: A novel Myc target gene, mina53, that is involved in cell proliferation. J Biol Chem 277: 35450-35459, 2002.

15. Teye K, Tsuneoka M, Arima N, Koda Y, Nakamura Y, Ueta Y, Shirouzu K and Kimura H: Increased expression of a Myc target gene Mina53 in human colon cancer. Am J Pathol 164: 205-216, 2004.

16. Tsuneoka M, Fujita H, Arima N, Teye K, Okamura T, Inutsuka H, Koda Y, Shirouzu K and Kimura H: Mina53 as a potential prognostic factor for esophageal squamous cell carcinoma. Clin Cancer Res 10: 7347-7356, 2004.

17. Lossos IS and Morgensztern D: Prognostic Biomarker in Diffuse Large B-cell Lymphoma. J Clin Oncol 24: 995-1007, 2006.

18. Magrath I: The pathogenesis of Burkitt's lymphoma. Adv Cancer Res 55: 133-270, 1990.

19. Willis TG and Dyer MJS: The role of immunoglobulin translocations in the pathogenesis of B-cell malignancies. Blood 96: 808-822, 2000.

20. Arcinas M, Heckman CA, Mehew JW and Boxer LM: Molecular mechanisms of transcriptional control of bcl-2 and c-myc in follicular and transformed lymphoma. Cancer Res 61: 5202-5206, 2001.

21. Evans LS and Hancock BW: Non-Hodgkin lymphoma. Lancet 362: 139-146, 2003

22. Lee JT, Innes Jr DJ and Williams M E: Sequential bcl-2 and c-myc oncogene rearrangements associated with the clinical transformation of non-Hodgkin's lymphoma. J Clin Invest 84: 1454-1459, 1989

23. Boxer LM and Dang CV: Translocations involving c-myc and c-myc function. Oncogene 20: 5595-5610, 2001.

24. Macpherson N, Lesack D, Klasa R, Horsman D, Connors JM, Barnett $\mathrm{M}$ and Gascoyne RD: Small noncleaved, non-Burkitt's (Burkitt-like) lymphoma: cytogenetics predict outcome and reflect clinical presentation. J Clin Oncol 17: 1558-1567, 1999.

25. Brandvold KA, Neiman P and Ruddell A: Angiogenesis is an early event in the generation of $m y c$-induced lymphomas. Oncogene 19: 2780-2785, 2000.

26. Neiman PE, Ruddell A, Jasoni C, Loring G, Thomas SJ, Brandvold KA, Lee R-m, Burnside J and Delrow J: Analysis of gene expression during myc oncogene-induced lymphomagenesis in the bursa of Fabricius. Proc Natl Acad Sci USA 98: 6378-6383, 2001.

27. Lombardi L, Newcomb E and Dalla-Favera R: Pathogenesis of Burkitt lymphoma: expression of an activated c-myc oncogene causes the tumorigenic conversion of EBV-infected human B lymphoblasts. Cell 49: 161-170, 1987.

28. Nussenzweig MC, Schmidt EV, Shaw AC, Sinn E, Campos-Torres J, Mathey-Prevot B, Pattengale PK and Leder P: A human immunoglobulin gene reduces the incidence of lymphomas in c-Myc-bearing transgenic mice. Nature 336: 446-450, 1988.

29. Acker B, Hoppe R, Colby T, Cox R, Kaplan H and Rosenberg S: Histologic conversion in the non-Hodgkin's lymphomas. J Clin Oncol 1: 11-16, 1983.

30. Horning S and Rosenberg S: The natural history of initially untreated low-grade non-Hodgkin's lymphomas. N Engl J Med 311: 1471-1475, 1984. 
31. Berard CW, Thomas LB, Axtell LM, Kruse M, Newell G and Kagan R: The relationship of histopathological subtype to clinical stage of Hodgkin's disease at diagnosis. Cancer Res 31: 1776-1785, 1971.

32. Medeiros LJ and Jaffe ES: Pathology of non-Hodgkin's lymphomas and Hodgkin's disease in Neoplastic Diseases of the Blood: In Wiernik PH, Canellos GP, Dutcher JP, and Kyle RA, (eds). Churchhill Livingstone, New York, pp753-805, 1996.

33. Jaffe ES, Harris NL, Stein H and Vardiman JW: World Health Organization classification of tumours. Pathology and genetics of tumours of hematopoietic and lymphoid tissues. IARC, Lyon, pp237-253, 2001

34. Cattoretti G, Becker MH, Key G, Duchrow M, Schluter C, Galle J and Gerdes J: Monoclonal antibodies against recombinant parts of the Ki-67 antigen (MIB 1 and MIB 3) detect proliferating cells in microwave-processed formalin-fixed paraffin sections. J Pathol 168: 357-363, 1992.

35. van Kemenade FJ, Raaphorst FM, Blokzijl T, Fieret E, Hamer KM, Satijn DPE, Otte AP and Meijer CJLM: Coexpression of BMI-1 and EZH2 polycomb-group proteins is associated with cycling cells and degree of malignancy in B-cell non-Hodgkin lymphoma. Blood 97: 3896-3901, 2001.
36. Tsuneoka M, Nishimune Y, Ohta K, Teye K, Tanaka H, Soejima M, Iida $H$, Inokuchi $T$, Kimura $H$ and Koda $Y$ : Expression of Mina53, a product of a Myc target gene in mouse testis. Int J Androl 29: 323-330, 2006.

37. Koji T, Izumi S, Tanno M, Moriuchi $T$ and Nakane PK: Localization in situ of c-myc mRNA and c-myc protein in adult mouse testis. Histochem J 20: 551-557, 1988.

38. Lossos IS, Alizadeh AA, Diehn M, Warnke R, Thorstenson Y, Oefner PJ, Brown PO, Botstein D and Levy R: Transformation of follicular lymphoma to diffuse large-cell lymphoma: Alternative patterns with increased or decreased expression of c-myc and its regulated genes. Proc Natl Acad Sci USA 99: 8886-8891, 2002.

39. Pelengaris S, Khan M and Evan GI: Suppression of Myc-induced apoptosis in beta cells exposes multiple oncogenic properties of Myc and triggers carcinogenic progression. Cell 109: 21-34, 2002 . 